\title{
Genetic control of iron concentration in Mesoamerican and Andean common bean seeds
}

\author{
Micheli Thaise Della Flora Possobom(1), Nerinéia Dalfollo Ribeiro(1), Lucas da Silva Domingues(2) \\ and Cleiton Renato Casagrande ${ }^{(1)}$
}

\begin{abstract}
(1) Universidade Federal de Santa Maria, Departamento de Fitotecnia, Avenida Roraima, № 1.000, Camobi, CEP 97105-900 Santa Maria, RS, Brazil. E-mail: michepossobom@yahoo.com.br, nerineia@hotmail.com, cleiton_casagrande@hotmail.com (2)Universidade Tecnológica Federal do Paraná, Curso de Agronomia, Estrada Boa Esperança, Km 04, Caixa Postal 157, CEP 85660-000 Dois Vizinhos, PR, Brazil. E-mail: lucassdomingues@hotmail.com
\end{abstract}

\begin{abstract}
The objective of this work was to evaluate the main differences in the genetic control of the iron concentration in Mesoamerican and Andean common bean seeds, in early generations, and to select recombinants with a high iron concentration in the seeds. $F_{1}, F_{1}$ reciprocal, $F_{2}, F_{2}$ reciprocal, and backcross $\left(\mathrm{BC}_{11}\right.$ and $\left.\mathrm{BC}_{12}\right)$ generations were produced by crosses between Mesoamerican (CNFP 10104 x CHC 01-175) and Andean (Cal 96 x Hooter) inbred lines. The expression of significant maternal effect was observed for the Mesoamerican gene pool. Iron concentration was higher in the seed coat of Mesoamerican common bean seeds (54.61 to 67.92\%) and in the embryo of Andean common bean seeds (69.40 to $73.44 \%$ ). High broad-sense heritability was obtained for iron concentration in Mesoamerican and Andean common bean seeds. Gains with the selection of higher magnitude, from 20.39 to 24.58\%, are expected in Mesoamerican common bean seeds. Iron concentration in common bean seeds showed a continuous distribution in $\mathrm{F}_{2}$, which is characteristic of quantitative inheritance in Mesoamerican and Andean common bean seeds. Recombinants with high iron concentration in seeds can be selected in both Mesoamerican and Andean common bean hybrids.
\end{abstract}

Index terms: Phaseolus vulgaris, biofortification, gain with selection, inheritance pattern, iron accumulation, maternal effect.

\section{Controle genético da concentração de ferro em sementes de feijão comum mesoamericano e andino}

Resumo - O objetivo deste trabalho foi avaliar as principais diferenças no controle genético da concentração de ferro em sementes de feijão comum mesoamericano e andino, em gerações precoces, e selecionar recombinantes com alta concentração de ferro nas sementes. Foram obtidas as gerações $F_{1}, F_{1}$ recíproco, $F_{2}, F_{2}$ recíproco e de retrocruzamentos $\left(\mathrm{RC}_{11}\right.$ e $\left.\mathrm{RC}_{12}\right)$, a partir de cruzamentos entre linhagens mesoamericanas (CNFP 10104 x CHC 01-175) e andinas (Cal 96 x Hooter). A expressão de efeito materno significativo foi observada no grupo gênico mesoamericano. A concentração de ferro foi maior no tegumento das sementes de feijão comum mesoamericano (54,61 a 67,92\%) e no embrião das sementes de feijão comum andino $(69,40$ a 73,44\%). Alta estimativa de herdabilidade no sentido amplo foi obtida para a concentração de ferro em sementes de feijão comum mesoamericano e andino. Ganhos com a seleção de maior magnitude, de 20,39 a 24,58\%, são esperados nas sementes de feijão comum mesoamericano. A concentração de ferro nas sementes de feijão comum apresentou distribuição contínua em $\mathrm{F}_{2}$, o que é característico de herança quantitativa em feijão comum mesoamericano e andino. Recombinantes com alta concentração de ferro nas sementes podem ser selecionados nos híbridos de feijão comum mesoamericano e andino.

Termos para indexação: Phaseolus vulgaris, biofortificação, ganho com a seleção, padrão de herança, acúmulo de ferro, efeito materno.

\section{Introduction}

The development of common bean cultivars biofortified for iron meets the global demand for food that can be used to combat anemia, which affects 1.62 billion people worldwide (Benoist et al., 2008). Mesoamerican and Andean common bean seeds have a large genetic variability for iron, and values from 29 to $159 \mathrm{mg} \mathrm{kg}^{-1}$ dry matter (DM) have been reported (Blair et al., 2009; Blair et al., 2010a, 2010b; Jost et al., 2013; Ribeiro et al., 2014a, 2014b), which allows for the selection and use of iron-rich cultivars for human consumption. 
However, the distribution of iron in the embryo and seed coat fractions of common bean seeds varies among gene pools and between lines of the same gene pool (Moraghan et al., 2002; Ariza-Nieto et al., 2007; Cvitanich et al., 2010; Ribeiro et al., 2012; Blair et al., 2013). This has direct consequences on iron bioavailability for the human organism (Lombardi-Boccia et al., 1995), in deciding when to start the process of selection of superior lines (Jost et al., 2009) and to determine the initial vigor of common bean seeds (Moraghan et al., 2002). Therefore, it is important to know the location of iron in the embryo and seed coat fractions, and to investigate if there is an expression of maternal effect for iron concentration, as already noted for Mesoamerican common bean seeds (Jost et al., 2009; Silva et al., 2013). For Andean common bean, research on the significant maternal effect for iron concentration in seeds was not found in the literature.

The inheritance pattern of the iron concentration in Mesoamerican and Andean common bean seeds is quantitative, since continuous distribution was observed among lines in the $\mathrm{F}_{7}$ (Ribeiro et al., 2014a), $\mathrm{F}_{7: 11}$ (Blair et al., 2009), and $\mathrm{F}_{10}$ (Blair et al., 2010b) generations. However, in early generations, no data on the type of frequency distribution for iron concentration was found for common bean seeds. In Mesoamerican common bean seeds, narrow-sense heritability for iron concentration was of an intermediate to a high magnitude in the $F_{2}$ generation (Jost et al., 2009). Therefore, the additive gene effect is predominant (Jost et al., 2009) and there are prospects of fixing the high iron concentration in common bean seeds in advanced generations. However, the study of iron concentration inheritance in Andean common bean seeds is unprecedented in the literature.

The objective of this work was to evaluate the main differences in the genetic control of the iron concentration in Mesoamerican and Andean common bean seeds in early generations, and to select recombinants with a high iron concentration in the seeds.

\section{Materials and Methods}

The genetic material consisted of hybrids obtained from the crosses between the CNFP 10104 x CHC 01-175 Mesoamerican inbred lines and the Cal $96 \mathrm{x}$ Hooter Andean inbred lines. The seeds of CNFP 10104 have a black seed coat and a low iron concentration of $71.7 \mathrm{mg} \mathrm{kg}^{-1} \mathrm{DM}$, and those from CHC 01-175, which is of the Carioca type, have a beige seed coat with brown streaks, besides a high iron concentration of $105.80 \mathrm{mg} \mathrm{kg}^{-1}$ DM (Ribeiro et al., 2013b). Cal 96 seeds have a dark-red seed coat with cream-colored stripes and a low iron concentration of $83.30 \mathrm{mg} \mathrm{kg}^{-1}$ DM, whereas those from Hooter have a cream-colored seed coat with medium red stripes and a high iron concentration of $159 \mathrm{mg} \mathrm{kg}^{-1} \mathrm{DM}$ (Ribeiro et al., 2014b). These inbred lines represent the most consumed types of common bean in Brazil, i.e., Carioca and black, and the ones with best prospects for exportation: cranberry, with a cream- and red-colored background.

The crossing blocks were installed in a greenhouse at the Department of Plant Sciences of Universidade Federal de Santa Maria (UFSM), located in the municipality of Santa Maria, in the state of Rio Grande do Sul, Brazil $\left(29^{\circ} 42^{\prime} \mathrm{S}, 53^{\circ} 4^{\prime} \mathrm{W}\right.$, at $95 \mathrm{~m}$ of altitude). Plants were grown in 8-L plastic pots filled with a mixture of soil from the experimental area - Argissolo Bruno-Acinzentado alítico úmbrico (Argisol, Hapludalf) -, Macplant commercial substrate, and carbonized rice husk, in a volumetric proportion of $3: 2: 1$. Controlled crosses were made by the interlacing method with emasculation of the flower bud. During the summer/fall of 2012, the $\mathrm{F}_{1}\left(q \mathrm{P}_{1} \times \hat{\delta} \mathrm{P}_{2}\right)$ and $\mathrm{F}_{1}$ reciprocal $\left(q \mathrm{P}_{2} \times \delta \mathrm{P}_{1}\right)$ seeds were produced for each hybrid combination. Remnant seeds of the $F_{1}$ hybrids and the parents were sown, and, in the winter/spring of 2012, the seeds of $F_{2}$ (natural self-fertilization of $F_{1}$ plants), $F_{2}$ reciprocal (natural self-fertilization of $F_{1}$ reciprocal plants), backcross $1\left(\mathrm{BC}_{11}: \uparrow \mathrm{F}_{1} \times \delta \mathrm{P}_{1}\right)$, and backcross $2\left(\mathrm{BC}_{12}: q \mathrm{~F}_{1} \times \widehat{\mathrm{P}_{2}}\right)$ were produced. The obtained pods were individually harvested at maturity and threshed manually, and the seeds were oven-dried at $65-70^{\circ} \mathrm{C}$ until they reached an average moisture content of $13 \%$.

The field experiments were carried out in the experimental area of the common bean breeding program of UFSM, in two growing seasons: normal rainy season, with sowing on November $9^{\text {th }}, 2012$, when temperatures ranged from 17.5 to $31.1^{\circ} \mathrm{C}$ and monthly rainfall from 72.8 to $293 \mathrm{~mm}$; and dry season, with sowing on March $3^{\text {rd }}$, 2013, when temperatures ranged from 9.5 to $26.6^{\circ} \mathrm{C}$ and monthly rainfall from 71.6 to $188.6 \mathrm{~mm}$. Both experiments were performed in a homogeneous soil area as to the soil physical 
and chemical properties. The soil was a Argissolo Bruno-Acinzentado alítico úmbrico, with the following chemical composition at the time of installation of the experiments: pH $6.1\left(\mathrm{H}_{2} \mathrm{O}\right) ; 50 \mathrm{~g} \mathrm{~kg}^{-1}$ organic matter; $13.5 \mathrm{mg} \mathrm{dm}^{-3} \mathrm{P} ; 60 \mathrm{mg} \mathrm{dm}^{-3} \mathrm{~K} ; 6.0 \mathrm{cmol}_{\mathrm{c}} \mathrm{dm}^{-3} \mathrm{Ca}$; and $2.9 \mathrm{cmol}_{\mathrm{c}} \mathrm{dm}^{-3} \mathrm{Mg}$. Soil was prepared in a conventional manner, and fertilization was performed in two times based on soil chemical analysis. The fertilizer used in both experiments at furrow sowing was $250 \mathrm{~kg} \mathrm{ha}^{-1}$ of the formula $\mathrm{N}-\mathrm{P}_{2} \mathrm{O}_{5}-\mathrm{K}_{2} \mathrm{O} 5-30-20$ (urea: $45 \% \mathrm{~N}$; superphosphate: $18 \% \mathrm{P}_{2} \mathrm{O}_{5}$; and potassium chloride: $60 \% \mathrm{~K}_{2} \mathrm{O}$ ). In addition, nitrogen fertilization was split at $20 \mathrm{~kg} \mathrm{ha}^{-1}$ urea $(45 \% \mathrm{~N})$ in the growth stage of the first trifoliate leaf (V3). Micronutrients were not added to the fertilizer.

The obtained generations $\left(\mathrm{F}_{1}, \mathrm{~F}_{1}\right.$ reciprocal; $\mathrm{F}_{2}, \mathrm{~F}_{2}$ reciprocal; $\mathrm{BC}_{11}$ and $\mathrm{BC}_{12}$ ) for each hybrid combination and the parents (CNFP 10104, CHC 01-175, Cal 96, and Hooter) differed in seed genetic variability and availability. Therefore, the number of rows and the sowing density were variable. For the parents and the $\mathrm{F}_{1}, \mathrm{~F}_{1}$ reciprocal, $\mathrm{BC}_{11}$, and $\mathrm{BC}_{12}$ generations, sowing was performed in a $1-\mathrm{m}$ row, using 15 seeds per meter for the parents and 10 seeds per meter for the others generations. The $\mathrm{F}_{2}$ and $\mathrm{F}_{2}$ reciprocal generations were constituted by 15 rows of $1 \mathrm{~m}$ and density of eight seeds per meter.

Management practices were similar and uniform in the two growing seasons. Irrigation was performed before the discovery of water deficit, as recommended by the Comissão Técnica Sul-Brasileira de Feijão (Informações..., 2010). Weed control was done by hand weeding, and insects were eliminated with use of the Engeo Pleno (Syngenta Brasil, São Paulo, SP, Brazil) insecticide (thiamethoxam + lambda-cyhalothrin), at the dose of $125 \mathrm{~mL} \mathrm{ha}^{-1}$. Disease control was not performed. At plant maturity, pod harvesting and threshing were performed manually to avoid contamination of the seeds by heavy metals. After the removal of impurities and broken seeds, the obtained seeds were oven-dried at 65 to $70^{\circ} \mathrm{C}$, until reaching an average moisture content of $13 \%$.

For the Mesoamerican parents and generations, random samples of six seeds per plant were ground in an analytical micro-mill to produce particles smaller than $1 \mathrm{~mm}$. For the Andean parents and generations, three seeds per plant were needed to obtain the same amount of flour. Furthermore, a random sample of
$0.5 \mathrm{~g}$ raw bean flour was used for the determination of iron concentration. The process was conducted by nitric-perchloric digestion $\left(\mathrm{HNO}_{3}+\mathrm{HClO}_{4}\right)$, in the volumetric proportion of $3: 1$, according to the methodology described by Miyazawa et al. (1999). The reading of the iron concentration was done in an atomic absorption spectrophotometer set to the wavelength of $248.3 \mathrm{~nm}$.

The maternal effect hypothesis was tested by comparing the means of the evaluated populations through the bilateral $\mathrm{t}$ test, at 5\% probability, for the contrasts $\mathrm{P}_{1} \times \mathrm{P}_{2}, \mathrm{P}_{1} \times \mathrm{F}_{1}, \mathrm{P}_{2} \times \mathrm{F}_{1}$ reciprocal, $F_{1} \times F_{1}$ reciprocal, and $F_{2} \times F_{2}$ reciprocal, for each hybrid combination and in each growing season. The distribution of iron in the seeds, in the embryo, and in the seed coat fractions was determined in the parents to confirm the maternal effect hypothesis. For this, 25 seeds of the CNFP 10104 and CHC 01-175 Mesoamerican inbred lines and 15 seeds of the Cal 96 and Hooter Andean inbred lines were randomly collected in three sub-samples of seeds. The removal of the seed coat of the seeds was performed according to Ribeiro et al. (2012).

The embryo and seed coat fractions were separately oven-dried at 65 to $70^{\circ} \mathrm{C}$, until reaching an average moisture of $13 \%$. Then, the samples were ground and weighed to obtain the total DM of each fraction of seeds. The determination of the iron concentration present in the embryo and in the seed coats was performed in a random sample of $0.5 \mathrm{~g}$ raw bean flour, which was digested in a nitric and perchloric acid solution (Miyazawa et al., 1999), and was quantified by an atomic absorption spectrophotometer. The $t$ test, at $5 \%$ probability, was applied to contrast embryo $\mathrm{x}$ seed coat in each growing season. The values of iron concentration in the embryo and seed coat were transformed to $\mathrm{mg} \%$ because these seed fractions represent different percentages of the total DM of the seed.

Genetic parameter estimates were obtained with the variances of the parents $\left(\mathrm{P}_{1}\right.$ and $\left.\mathrm{P}_{2}\right)$ and the $\mathrm{F}_{1}, \mathrm{~F}_{2}, \mathrm{BC}_{11}$, and $\mathrm{BC}_{12}$ generations. The broad-sense heritability was estimated by the expression $h_{b}^{2}=\sigma_{G}^{2} / \sigma_{P}^{2}$, whereas the narrow-sense heritability was obtained by $\mathrm{h}_{\mathrm{n}}^{2}=\sigma_{\mathrm{A}}^{2} / \sigma_{\mathrm{P}}^{2}$, using the backcross method, in which: $\sigma_{\mathrm{A}}^{2}=2 \sigma_{\mathrm{F} 2}^{2}-\left(\sigma_{\mathrm{BC} 11}^{2}+\sigma_{\mathrm{BC} 12}^{2}\right)$ is the additive variance, $\sigma_{\mathrm{P}}^{2}=\sigma_{\mathrm{F} 2}^{2}$ is the phenotypic variance, and $\sigma_{\mathrm{E}}^{2}=1 / 3\left(\sigma_{\mathrm{F} 1}^{2}\right.$ 
$\left.+\sigma_{\mathrm{P} 1}^{2}+\sigma_{\mathrm{P} 2}^{2}\right)$ is the environmental variance in $F_{2}$ (Warner, 1952).

The gain expected with the selection of $10 \%$ of the $F_{2}$ plants with higher iron concentration in the seeds was estimated using the expressions: $\Delta \mathrm{G}=\mathrm{DS} \times \mathrm{h}_{\mathrm{n}}^{2}$, considering narrow-sense heritability; $\Delta \mathrm{G}=\mathrm{DS} \times \mathrm{h}_{\mathrm{b}}^{2}$, considering broad-sense heritability; and $\Delta \mathrm{G}(\%)=(\Delta \mathrm{Gx} 100) / \overline{\mathrm{F}}_{2}$. In this case, DS is the selection differential expressed by $\overline{\mathrm{X}}_{\mathrm{S}}-\overline{\mathrm{X}}_{0}$, in which $\overline{\mathrm{X}}_{\mathrm{S}}$ is the average of selected $F_{2}$ plants, and $\bar{X}_{0}$ is the average of $\mathrm{F}_{2}$ plants (Falconer, 1987).

The data obtained for the $F_{2}$ plants were subjected to the Lilliefors test to check the type of distribution (continuous or discontinuous) observed for the iron concentration in common bean seeds. Analyses were performed with the aid of the Microsoft Office Excel spreadsheet and the Genes software (Cruz, 2006).

\section{Results and Discussion}

The parents of the Mesoamerican inbred lines, CNFP 10104 and CHC 01-175, contrasted for iron concentration in seeds only in the normal rainy season (Table 1). In the dry season, the parents of the Mesoamerican lines did not differ as to iron concentration, and the obtained values were lower than those observed in the normal rainy season and different from those previously described by Ribeiro et al. (2013b). This can be attributed to the lower average minimum and maximum temperatures and the lower amount of precipitation during the pod-filling to maturity stages of the plants in the dry season, resulting in a lower accumulation of iron in the seeds. Lower translocation of iron to common bean seeds was also reported by Silva et al. (2012) in bean lines grown in the dry season, with sowing in February, in the state of Minas Gerais, Brazil, when rainfall rates were low.

However, in the Cal $96 \times$ Hooter hybrids of the Andean inbred lines, the contrast $\mathrm{P}_{1} \times \mathrm{P}_{2}$ was significant in the dry season; therefore, plants with genetic variability for iron concentration in bean seeds were obtained. In the normal rainy season, the Andean parents and the produced generations were very sensitive to the maximum temperatures recorded, resulting in a large abortion of flowers and pods. Therefore, the plants of the parents and of the $F_{1}, F_{2}$, and backcross generations did not produce enough seeds for the analysis of iron concentration. Moreover, in the Andean gene pool, many plants of the obtained generations showed characteristics typical of genetic incompatibility, such as weak vegetative growth, reduced root growth, dwarfism, plant sterility, and absence of roots or formation of adventitious roots in the hypocotyl region. These problems of genetic incompatibility in crosses have been reported between gene pools in common bean (Vieira et al., 2005; Bomblies \& Weigel, 2007). The

Table 1. Number of plants (NP), mean iron concentration, and respective standard deviations obtained in the parents $\left(\mathrm{P}_{1}\right.$ and $\mathrm{P}_{2}$ ) and in the $\mathrm{F}_{1}, \mathrm{~F}_{1}$ reciprocal, $\mathrm{F}_{2}$, and $\mathrm{F}_{2}$ reciprocal generations of the CNFP $10104\left(\mathrm{P}_{1}\right)$ x CHC 01-175 ( $\left.\mathrm{P}_{2}\right)$ (normal rainy and dry seasons) and the Cal $96\left(\mathrm{P}_{1}\right) \times$ Hooter $\left(\mathrm{P}_{2}\right)$ (dry season) hybrids, as well as probability by the test for the contrasts $\mathrm{P}_{1} \times \mathrm{P}_{2}, \mathrm{P}_{1} \times \mathrm{F}_{1}, \mathrm{P}_{2} \times \mathrm{F}_{1}$ reciprocal, $\mathrm{F}_{1} \times \mathrm{F}_{1}$ reciprocal, and $\mathrm{F}_{2} \times \mathrm{F}_{2}$ reciprocal.

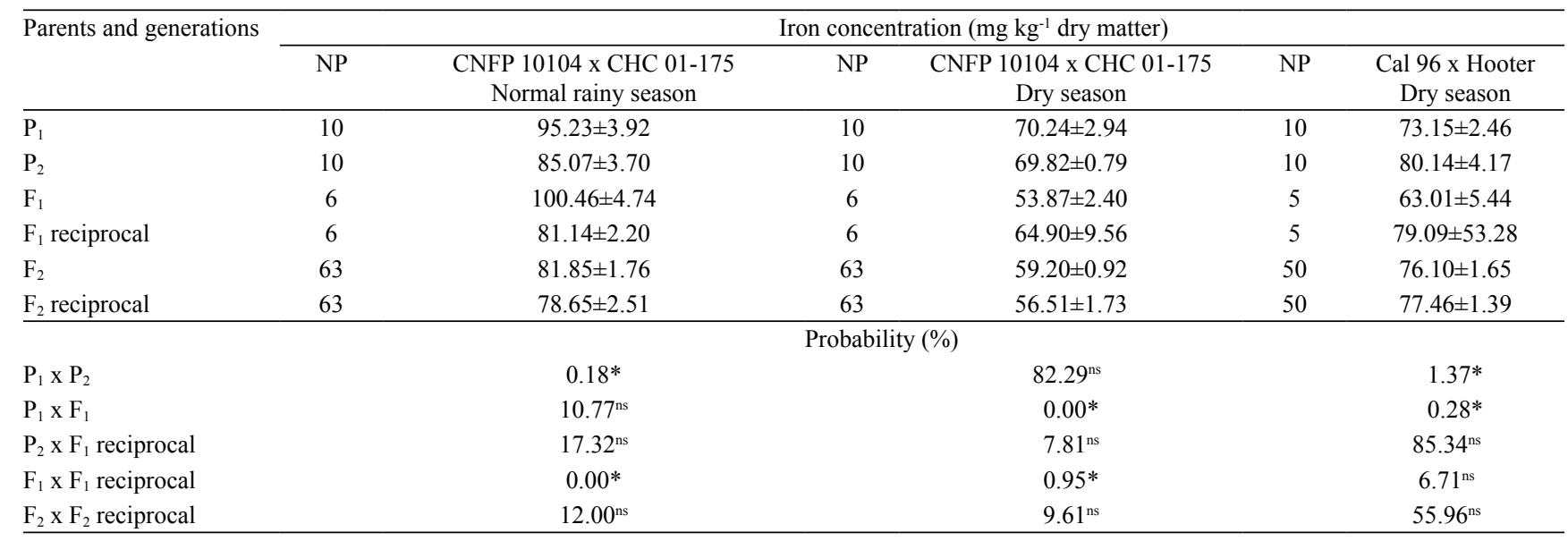

*Significant by the $\mathrm{t}$ test, at $5 \%$ probability. ${ }^{\mathrm{n}}$ Nonsignificant. 
diversity of common bean races can naturally generate the incorporation of genes (gene flow) between different gene pools (Blair et al., 2010a), suggesting that genes of the Mesoamerican gene pool can be present in the Andean gene pool; however, this is a hypothesis that still needs confirmation.

The contrast $\mathrm{F}_{1} \times \mathrm{F}_{1}$ reciprocal was significant in the CNFP 10104 x CHC 01-175 hybrids in the two growing seasons, characterizing an expression of maternal effect for iron concentration (Table 1). In the present study, the generation of the seed coat was considered in order to characterize the evaluated generation. Seeds with $\mathrm{F}_{1}$ seed coat refer to seeds in the $F_{1}$ generation, and seeds with $F_{2}$ seed coat refer to seeds in the $F_{2}$ generation. Therefore, the iron concentration in Mesoamerican common bean seeds is dependent on the seed coat, which is a maternal tissue, confirming previous results obtained by Jost et al. (2009) and Silva et al. (2013). In this case, the expression of cross will be observed only in the $\mathrm{F}_{2}$ generation seeds. Therefore, the selection for increased iron concentration in Mesoamerican common bean seeds should be done on the $\mathrm{F}_{3}$ generation seeds, when it will be possible to identify recombinants with genetic variability for iron.

The seed coat of Mesoamerican common bean seeds represented $8.74-10.91 \%$ of the total DM of seeds; in addition, 54.61 to $67.92 \%$ of total iron was located in the seed coat of CHC 01-175, in the normal rainy season, and of CNFP 10104, in the dry season, respectively (Table 2). Therefore, the highest accumulation of iron was found in the seed coats of Mesoamerican common bean seeds, which agrees with the results of Ariza-Nieto et al. (2007), Cvitanich et al. (2010), and Ribeiro et al. (2012). The iron present in the seed coat of the common bean seeds was more bioavailable to the human body (Lombardi-Boccia et al., 1995). However, the black and red common bean seeds showed high tannin and polyphenol contents in the seed coat, which are potential inhibitors of iron absorption (Lombardi-Boccia et al., 1995; Ariza-Nieto et al., 2007). Therefore, in the development process of common bean cultivars of Mesoamerican origin and biofortified for iron, the identification of lines with high iron concentration in seeds is as important as the selection of lines that accumulate more iron in the seed coat of the clearest seeds, because these present the highest iron bioavailability.
In the Cal $96 \times$ Hooter hybrids, the contrast $F_{1} \times F_{1}$ reciprocal was not significant, indicating that there was no expression of maternal effect for iron concentration in the Andean common bean seeds (Table 1), which is unprecedented for this gene pool. Therefore, in the Andean gene pool, the seeds of the $F_{1}$ generation represented the product of the fertilization between the parents, because most of the iron (69.40 to $73.44 \%)$ was concentrated in the embryo of the seeds (Table 2). Ariza-Nieto et al. (2007) and Cvitanich et al. (2010) also described Cal 96 as a major iron accumulator line in the seed embryo. In this case, the selection for increased iron concentration in the Andean common bean should be done on the $\mathrm{F}_{2}$ generation seeds, when maximum genetic variability can be accessed.

The distribution of iron between the embryo and the seed coat fractions of common bean seeds can vary among gene pools, as observed in the present study and by Ariza-Nieto et al. (2007), Cvitanich et al. (2010), Ribeiro et al. (2012), and Blair et al. (2013). Since iron is accumulated more in the embryo of the Andean

Table 2. Percentage of dry matter, iron concentration, percentage of iron in the embryo and in the common bean seed coat of the CNFP 10104 and CHC 01-175 (normal rainy and dry seasons) Mesoamerican inbred lines, and of the Cal 96 and Hooter (dry season) Andean inbred lines.

\begin{tabular}{|c|c|c|c|c|}
\hline Fraction & Inbred lines & Dry matter $(\%)$ & Iron $\left(\mathrm{mg} \mathrm{kg}^{-1}\right)$ & Iron $(\%)$ \\
\hline & \multicolumn{4}{|c|}{ Mesoamerican inbred lines, normal rainy season } \\
\hline \multirow{3}{*}{ Embryo } & CNFP 10104 (a) & 89.15 & 62.96 & 33.81 \\
\hline & CHC 01-175 (b) & 91.26 & 69.41 & 45.38 \\
\hline & $\mathrm{a}-\mathrm{b}$ & $-2.11^{*}$ & $-6.45^{*}$ & $-11.57 *$ \\
\hline \multirow{4}{*}{ Seed coat } & CNFP 10104 (a) & 10.85 & 123.12 & 66.19 \\
\hline & CHC 01-175 (b) & 8.74 & 83.40 & 54.61 \\
\hline & $a-b$ & $2.11 *$ & $39.72 *$ & $11.58 *$ \\
\hline & \multicolumn{4}{|c|}{ Mesoamerican inbred lines, dry season } \\
\hline \multirow{3}{*}{ Embryo } & CNFP 10104 (a) & 89.09 & 58.76 & 32.07 \\
\hline & CHC 01-175 (b) & 91.09 & 64.22 & 42.90 \\
\hline & $a-b$ & $-2.00 *$ & $-5.46^{\mathrm{ns}}$ & $-10.83 *$ \\
\hline \multirow{3}{*}{ Seed coat } & CNFP 10104 (a) & 10.91 & 123.75 & 67.92 \\
\hline & CHC 01-175 (b) & 8.91 & 85.41 & 57.10 \\
\hline & $a-b$ & $2.00 *$ & $38.34 *$ & $10.82 *$ \\
\hline & \multicolumn{4}{|c|}{ Andean inbred lines, dry season } \\
\hline \multirow{3}{*}{ Embryo } & Cal 96 (c) & 92.24 & 68.90 & 69.40 \\
\hline & Hooter (d) & 92.85 & 83.30 & 73.44 \\
\hline & $\mathrm{c}-\mathrm{d}$ & $-0.61^{\mathrm{ns}}$ & $-14.40^{\mathrm{ns}}$ & $-4.04^{\mathrm{ns}}$ \\
\hline \multirow{3}{*}{ Seed coat } & Cal 96 (c) & 7.75 & 30.34 & 30.60 \\
\hline & Hooter (d) & 7.14 & 30.47 & 26.56 \\
\hline & $c-d$ & $0.61^{\mathrm{ns}}$ & $-0.13^{\mathrm{ns}}$ & $4.04^{\mathrm{ns}}$ \\
\hline
\end{tabular}

*Significant by the $t$ test, at $5 \%$ probability. ${ }^{\mathrm{n}}$ Nonsignificant. 
common bean seeds (Table 2), the selection of superior lines in breeding programs for biofortification of iron should start in seeds of the $F_{2}$ generation for this gene pool. However, in the embryo of Andean common bean seeds, large quantities of phytate were found, which have an inhibitory action on iron absorption by the human body (Lombardi-Boccia et al., 1995; Ariza-Nieto et al., 2007). Phytates, compared to polyphenols, were weak inhibitors of iron absorption in common bean (Ariza-Nieto et al., 2007); therefore, a drastic reduction in the bioavailability of the iron present in the embryo is not expected. Moreover, the iron present in the embryo of the common bean seed was directly available for plant growth, resulting in an increased initial seedling vigor (Moraghan et al., 2002). Increased iron availability in the embryo of the common bean seed probably occurred due to the presence of ferritin, an iron-storage protein contained in the amyloplast of the seed embryo, acting as a regulator of iron availability to the needs of the seedling (Cvitanich et al., 2010).

Genetic variance was higher than environmental variance in the CNFP 10104 x CHC 01-175 hybrids, in the two growing seasons (Table 3). Therefore, high broad-sense heritability estimates were obtained for iron concentration in Mesoamerican bean seeds, with values of 68.54 and $70.20 \%$ in the normal rainy season and in the dry season, respectively. A similar value of broad-sense heritability was obtained by Jost et al. (2009) for iron concentration in the seeds of the Minuano x Diamante Negro common bean hybrids, also of Mesoamerican origin. In the Cal $96 \mathrm{x}$ Hooter hybrids, high broad-sense heritability estimates were also observed $\left(h^{2} b=62.27 \%\right)$, indicating that the inheritance pattern of the iron concentration is similar in the Mesoamerican and Andean common bean. This is the first report of heritability estimates for iron concentration in Andean common bean. Therefore, considering the magnitude of the broadsense heritability estimates obtained in the present study and by Jost et al. (2009), it is possible to infer that the selection to increase iron concentration in Mesoamerican and Andean common bean seeds will be facilitated because the greatest proportion of the variation observed will be caused by genetic factors.

Narrow-sense heritability was determined only in the CNFP 10104 x CHC 01-175 hybrids in the normal rainy season and showed an intermediate magnitude $\left(h^{2} \mathrm{n}=54.69 \%\right)$, similar to the estimates found by Jost et al. (2009) in Mesoamerican common bean. Narrow-sense heritability is important in autogamous

Table 3. Estimates of means, genetic parameters, and expected gains with the selection for iron concentration in the common bean seeds of the CNFP 10104 x CHC 01-175 (normal rainy and dry seasons) and the Cal 96 x Hooter (dry season) hybrids.

\begin{tabular}{|c|c|c|c|}
\hline \multirow[t]{2}{*}{ Parents and generations } & \multicolumn{3}{|c|}{ Iron concentration ( $\mathrm{mg} \mathrm{kg}^{-1}$ dry matter) } \\
\hline & $\begin{array}{l}\text { CNFP } 10104 \text { x CHC 01-175 } \\
\text { - normal rainy season }\end{array}$ & $\begin{array}{c}\text { CNFP } 10104 \text { x CHC 01-175 } \\
\text { - dry season }\end{array}$ & $\begin{array}{l}\text { Cal } 96 \times \text { Hooter } \\
- \text { dry season }\end{array}$ \\
\hline$\overline{\text { Mean }}$ & 87.07 & 62.42 & 74.83 \\
\hline Phenotypic variance $\left(\sigma_{\mathrm{P}}^{2}\right)$ & 110.84 & 57.84 & 82.57 \\
\hline Environmental variance $\left(\sigma_{\mathrm{E}}^{2}\right)$ & 34.87 & 17.24 & 31.15 \\
\hline Genetic variance $\left(\sigma^{2} \mathrm{G}\right)$ & 75.97 & 40.61 & 51.41 \\
\hline Additive variance $\left(\sigma^{2} \mathrm{~A}\right)$ & 60.62 & - & - \\
\hline Broad-sense heritability $\left(h^{2} b\right)$ & 68.54 & 70.20 & 62.27 \\
\hline Narrow-sense heritability $\left(h^{2} n\right)$ & 54.69 & - & - \\
\hline Minimum value in parents & 73.35 & 64.64 & 67.27 \\
\hline Maximum value in parents & 99.83 & 79.06 & 89.89 \\
\hline Minimum value in $F_{2}$ & 61.32 & 32.66 & 62.72 \\
\hline Maximum value in $F_{2}$ & 132.99 & 87.94 & 96.63 \\
\hline Selected plant in $\mathrm{F}_{2}$ & $\begin{array}{c}72,12,4,46,21,77,68,85,96 \\
98,25, \text { and } 23\end{array}$ & $\begin{array}{c}120,87,15,86,27,84,13,21 \\
28,88,23 \text {, and } 51\end{array}$ & $\begin{array}{c}39,97,98,91,27,95,43, \\
99,89 \text {, and } 21\end{array}$ \\
\hline Original mean in $\mathrm{F}_{2}$ & 80.25 & 57.85 & 76.78 \\
\hline Mean of selected plants & 102.27 & 75.71 & 93.45 \\
\hline Selection differential (SD) & 22.01 & 17.86 & 16.67 \\
\hline Selection gain $(\Delta \mathrm{G})$ & 16.36 & 14.22 & 9.80 \\
\hline Selection gain $(\Delta \mathrm{G} \%)$ & 20.39 & 24.58 & 12.77 \\
\hline Predicted mean after the first selection cycle & 96.62 & 72.07 & 86.59 \\
\hline
\end{tabular}


plant breeding, because it considers additive variance. Since there is higher influence of the additive genetic effect for iron concentration in common bean grains (Jost et al., 2009), the fixation of favorable alleles will be verified in the generation with a higher level of endogamy. In the dry season, narrow-sense heritability estimates were not observed for the evaluated hybrid combinations, because few plants of the $\mathrm{BC}_{11}$ and $\mathrm{BC}_{12}$ generations were obtained. These plants produced few seeds for the analysis of iron concentration.

The iron concentration in the seeds ranged from 61.32 to $132.99 \mathrm{mg} \mathrm{kg}^{-1} \mathrm{DM}$ in the normal rainy season and from 32.66 to $87.94 \mathrm{mg} \mathrm{kg}^{-1} \mathrm{DM}$ in the dry season, in $\mathrm{F}_{2}$ plants of the CNFP 10104 x CHC 01-175 hybrids, with continuous distribution near normal, characterizing quantitative inheritance (Table 3, Figures 1 A and 1 B). Continuous distribution for the iron concentration in Mesoamerican common bean seeds was also previously described among lines in the $\mathrm{F}_{7}$ (Ribeiro et al., 2014a) and $\mathrm{F}_{10}$ (Blair et al., $2010 \mathrm{~b})$ generations. These results may indicate that the inheritance of iron concentration in Mesoamerican common bean seeds is quantitative.

For recombinants obtained from the Mesoamerican gene pool, transgressive segregation was observed for the iron concentration in the seeds (Figures $1 \mathrm{~A}$ and $1 \mathrm{~B}$ ). Therefore, the selection of individual plants with high iron concentration is possible at an early generation. In the present study, a $F_{2}$ plant with iron concentration equal to $132.99 \mathrm{mg} \mathrm{kg}^{-1} \mathrm{DM}$ was obtained in the normal rainy season, which represented an increase of $33.21 \%$ in the concentration of this mineral in comparison to CNFP 10104 with $99.83 \mathrm{mg} \mathrm{kg}^{-1} \mathrm{DM}$ (Table 3). This percentage was lower than the $94 \%$ increase in iron concentration in the Mesoamerican common bean seeds obtained in early generations by Jost et al. (2009).

In the CNFP $10104 \times$ CHC 01-175 hybrids, nine $\mathrm{F}_{2}$ plants with iron concentration in the seeds above $95 \mathrm{mg} \mathrm{kg}^{-1} \mathrm{DM}$ were obtained in the normal rainy season (Figure $1 \mathrm{~A}$ ), and this value is considered high for common bean lines (Ribeiro et al., 2013a). However, gains with the selection of higher magnitude, from 20.39 to $24.58 \%$, were obtained in Mesoamerican common bean (Table 3). These estimates are more accurate because they were obtained in two growing seasons, and higher increases in the iron concentration in the seeds of this gene pool are expected. However, dominance effects need to be considered because these gains were based on broad-sense heritability estimates.
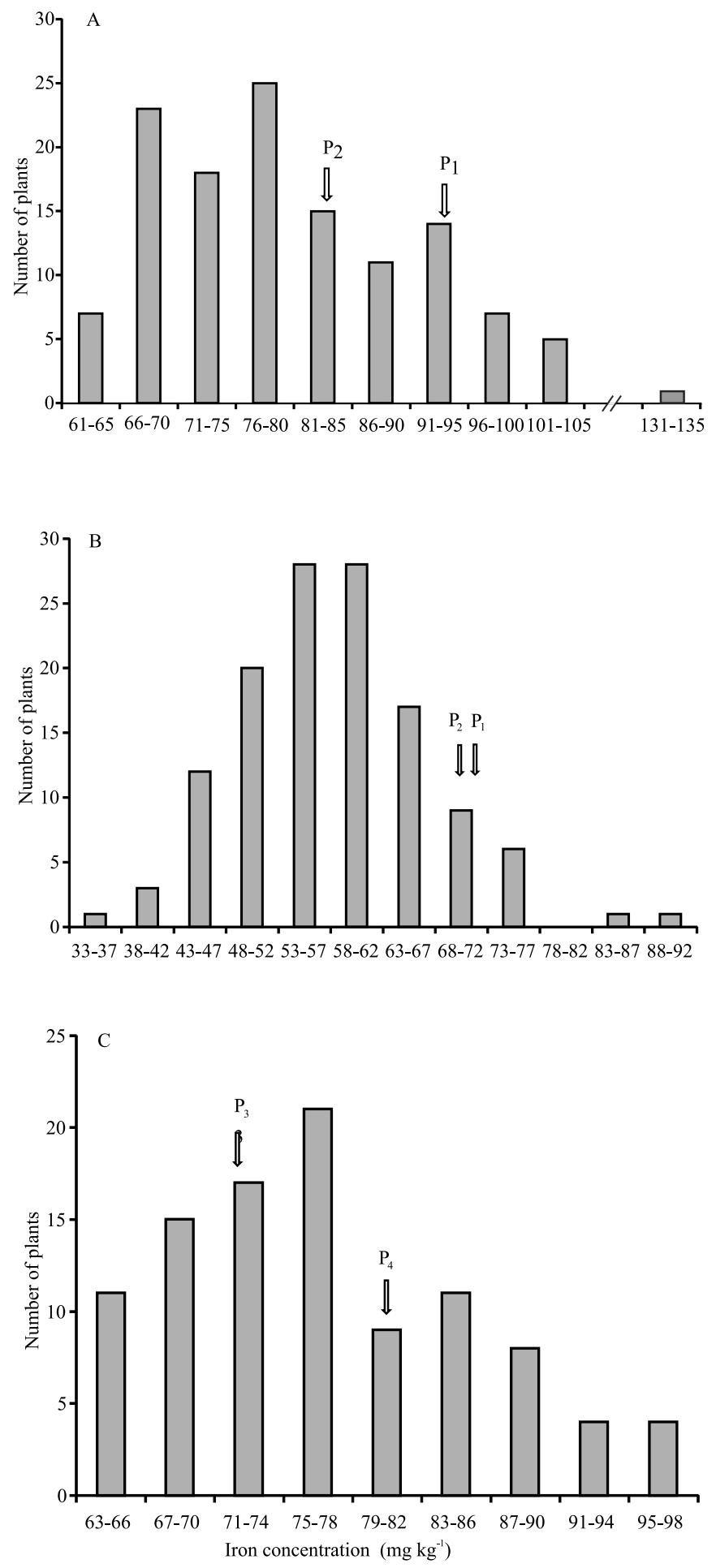

Figure 1. Frequency distribution for iron concentration in $\mathrm{F}_{2}$ plants of the cross between CNFP 10104 x CHC 01-175 in the normal (A) and dry seasons (B), and of the cross between Cal $96 \times$ Hooter in the dry season $(C)$. The arrows refer to the parents: $\mathrm{P}_{1}, \mathrm{CNFP} 10104 ; \mathrm{P}_{2}, \mathrm{CHC}$ 01-175; $\mathrm{P}_{3}$, Cal 96; and $\mathrm{P}_{4}$, Hooter. 
In the Andean gene pool, the amplitude of the iron concentration in the seeds of $\mathrm{F}_{2}$ plants ranged from 62.72 to $96.63 \mathrm{mg} \mathrm{kg}^{-1} \mathrm{DM}$, and a continuous distribution was observed (Table 3 and Figure $1 \mathrm{C}$ ). These values were higher than those reported in $67 \mathrm{~F}_{5: 7}$ lines of Andean common bean seeds, which also showed a quantitative inheritance pattern for the iron concentration in common bean seeds (Cichy et al., 2009). In the present study, four recombinants were obtained in $\mathrm{F}_{2}$ with high iron concentration in the seeds (Figure $1 \mathrm{C}$ ), considering the criterion proposed by Ribeiro et al. (2013a) and the gains with the selection of lower magnitude $(12.77 \%)$. However, this estimate is less accurate because it was obtained in one growing season.

From the tested crosses, it was possible to identify recombinants with a high iron concentration in the seeds, in early generations, in the two gene pools evaluated. The selection of individual $\mathrm{F}_{2}$ plants and the advances of these generations are promising for iron biofortification programs and may result in new common bean cultivars of the best-accepted commercial groups for consumption in Brazil (Carioca and black) and of great export demand.

\section{Conclusions}

1. Iron concentration presents a maternal effect in Mesoamerican common bean seeds, and its heritability in early generations is of a high magnitude in both Mesoamerican and Andean common bean.

2. The percentage of iron is higher in the seed coat of Mesoamerican common bean seeds.

3. Gains with the selection of high magnitude, from 20.39 to $24.58 \%$, for iron concentration are expected in Mesoamerican common bean.

4. Iron concentration is characteristic of quantitative inheritance in both Mesoamerican and Andean common bean.

5. Recombinants with high iron concentration in common bean seeds can be selected in both Mesoamerican and Andean gene pools.

\section{Acknowledgments}

To Conselho Nacional de Desenvolvimento Científico e Tecnológico (CNPq), for financial support and scholarship granted; and to Coordenação de Aperfeiçoamento de Pessoal de Nível Superior (Capes), for the grants awarded.

\section{References}

ARIZA-NIETO, M.; BLAIR, M.W.; WELCH, R.M.; GLAHN, P. Screening of iron bioavailability patterns in eight bean (Phaseolus vulgaris L.) genotypes using the Caco-2 cell in vitro model. Journal of Agricultural and Food Chemistry, v.55, p.7950-7956, 2007. DOI: 10.1021/jf070023y.

BENOIST, B. de; MCLEAN, E.; EGLI, I.; COGSWELL, M. Worldwide prevalence of anaemia 1993-2005: WHO global database on anaemia. Geneva: World Health Organization, 2008. 40p.

BLAIR, M.W.; ASTUDILLO, C.; GRUSAK, M.A.; GRAHAM, R.; BEEBE, S.E. Inheritance of seed iron and zinc concentrations in common bean (Phaseolus vulgaris L.). Molecular Breeding, v.23, p.197-207, 2009. DOI: 10.1007/s11032-008-9225-z.

BLAIR, M.W.; GONZÁLEZ, L.F.; KIMANI, P.M.; BUTARE, L. Genetic diversity, inter-gene pool introgression and nutritional quality of common beans (Phaseolus vulgaris L.) from Central Africa. Theoretical and Applied Genetics, v.121, p.237-248, 2010a. DOI: 10.1007/s00122-010-1305-x.

BLAIR, M.W.; IZQUIERDO, P.; ASTUDILLO, C.; GRUSAK, M.A. A legume biofortification quandary: variability and genetic control of seed coat micronutrient accumulation in common beans. Frontiers in Plant Science, v.4, article 275, 2013. DOI:10.3389/ fpls.2013.00275.

BLAIR, M.W.; MEDINA, J.I.; ASTUDILLO, C.; RENGIFO, J.; BEEBE, S.E.; MACHADO, G.; GRAHAM, R. QTL for seed iron and zinc concentration and content in a Mesoamerican common bean (Phaseolus vulgaris L.) population. Theoretical and Applied Genetics, v.121, p.1059-1070, 2010b. DOI: 10.1007/ s00122-010-1371-0.

BOMBLIES, K.; WEIGEL, D. Hybrid necrosis: autoimmunity as a potential gene-flow barrier in plant species. Nature Reviews Genetics, v.8, p.382-393, 2007. DOI: 10.1038/nrg2082.

CICHY, K.A.; CALDAS, G.V.; SNAPP, S.S.; BLAIR, M.W. QTL analysis of seed iron, zinc, and phosphorus levels in an Andean bean population. Crop Science, v.49, p.1742-1750, 2009. DOI: 10.2135/cropsci2008.10.0605.

CRUZ, C.D. Programa Genes: biometria. Viçosa: Ed. UFV, 2006. $382 \mathrm{p}$.

CVITANICH, C.; PRZYBYŁOWICZ, W.J.; URBANSKI, D.F.; JURKIEWICZ, A.M.; MESJASZ-PRZYBYŁOWICZ, J.; BLAIR, M.W.; ASTUDILlO, C.; JENSEN, E.O.; STOUGAARD, J. Iron and ferritin accumulate in separate cellular locations in Phaseolus seeds. BMC Plant Biology, v.10, article 26, 2010. DOI: 10.1186/1471-2229-10-26.

FALCONER, D.S. Introdução à genética quantitativa. Viçosa: UFV, 1987. 279p.

INFORMAÇÕES técnicas para o cultivo de feijão na Região Sul brasileira 2009. Florianópolis: Epagri, 2010. 163p.

JOST, E.; RIBEIRO, N.D.; CERUTTI, T.; POERSCH, N.L.; MAZIERO, S.M. Potencial de aumento do teor de ferro em grãos de feijão por melhoramento genético. Bragantia, v.68, p.35-42, 2009. DOI: $10.1590 / \mathrm{S} 0006-87052009000100005$. 
JOST, E.; RIBEIRO, N.D.; MAZIERO, S.M.; POSSOBOM, M.T.D.F.; ROSA, D.P.; DOMINGUES, L. da S. Comparison among direct, indirect and index selections on agronomic traits and nutritional quality traits in common bean. Journal of the Science of Food and Agriculture, v.93, p.1097-1104, 2013. DOI: 10.1002/ jsfa.5856.

LOMBARDI-BOCCIA, G.; DE SANTIS, N.; DI LULLO, G.; CARNOVALE, E. Impact of processing on Fe dialysability from bean (Phaseolus vulgaris L.). Food Chemistry, v.53, p.191-195, 1995. DOI: 10.1016/0308-8146(95)90787-8.

MIYAZAWA, M.; PAVAN, M.A.; MURAOKA, T.; CARMO, C.A.F.S.; MELLO, W.J. Análises químicas de tecido vegetal. In: SILVA, F.C. da (Ed.). Manual de análises químicas de solos, plantas e fertilizantes. Brasília: Embrapa Comunicação para Transferência de Tecnologia; Rio de Janeiro: Embrapa Solos; Campinas: Embrapa Informática Agropecuária, 1999. p.171-223.

MORAGHAN, J.T.; PADILLA, J.; ETCHEVERS, J.D.; GRAFTON, K.; ACOSTA-GALLEGOS, J.A. Iron accumulation in seed of common bean. Plant and Soil, v.246, p.175-183, 2002. DOI: $10.1023 / \mathrm{A}: 1020616026728$.

RIBEIRO, N.D.; DOMINGUES, L. da S.; ZEMOLIN, A.E.M.; POSSOBOM, M.T.D.F. Selection of common bean lines with high agronomic performance and high calcium and iron concentrations. Pesquisa Agropecuária Brasileira, v.48, p.1368-1375, 2013a. DOI: $10.1590 / \mathrm{S} 0100-204 X 2013001000008$.

RIBEIRO, N.D.; JOST, E.; MAZIERO, S.M.; STORCK, L.; ROSA, D.P. Selection of common bean lines with high grain yield and high grain calcium and iron concentrations. Revista Ceres, v.61, p.77-83, 2014a. DOI: 10.1590/ S0034-737X2014000100010.
RIBEIRO, N.D.; MAMBRIN, R.B.; STORCK, L.; PRIGOL, M.; NOGUEIRA, C.W. Combined selection for grain yield, cooking quality and minerals in the common bean. Revista Ciência Agronômica, v.44, p.869-877, 2013b. DOI: 10.1590/ S1806-66902013000400025.

RIBEIRO, N.D.; MAZIERO, S.M.; PRIGOL, M.; NOGUEIRA, C.W.; ROSA, D.P.; POSSOBOM, M.T.D.F. Mineral concentrations in the embryo and seed coat of common bean cultivars. Journal of Food Composition and Analysis, v.26, p.89-95, 2012. DOI: 10.1016/j.jfca.2012.03.003.

RIBEIRO, N.D.; RODRIGUES, J. de A.; PRIGOL, M.; NOGUEIRA, C.W.; STORCK, L.; GRUHN, E.M. Evaluation of special grains bean lines for grain yield, cooking time and mineral concentrations. Crop Breeding and Applied Biotechnology, v.14, p.15-22, 2014b. DOI: 10.1590/S1984-70332014000100003.

SILVA, C.A.; ABREU, A. de F.B.; RAMALHO, M.A.P. Genetic control of zinc and iron concentration in common bean seeds. African Journal of Agricultural Research, v.8, p.1001-1008, 2013. DOI: 10.5897/AJAR12.2172.

SILVA, C.A.; ABREU, A. de F.B.; RAMALHO, M.A.P.; CORRÊA, A.D. Interaction genotype by season and its influence on the identification of beans with high content of zinc and iron. Bragantia, v.71, p.336-341, 2012. DOI: 10.1590/S0006-87052012005000037.

VIEIRA, C.; BORÉM, A.; RAMALHO, M.A.P.; CARNEIRO, J.E.S. Melhoramento do feijão. In: BORÉM, A. (Ed.). Melhoramento de espécies cultivadas. 2.ed. Viçosa: Ed. UFV, 2005. p.301-391.

WARNER, J.N. A method for estimating heritability. Agronomy Journal, v.44, p.427-430, 1952. DOI: 10.2134/agronj1952.00021 $962004400080007 x$.

Received on October 18, 2014 and accepted on April 6, 2015 